\title{
Otolith Shape Analyses and Dimensions of the Anchovy Engraulis encrasicolus L. in the Black and Marmara Seas
}

(Analisis Bentuk Otolit dan Dimensi Ikan Bilis Engraulis encrasicolus L. di Laut Hitam dan Marmara)

\author{
MELEK ZENGIN*, SEMRA SAYGIN \& NAZMI POLAT
}

\begin{abstract}
Otoliths, which can be used for the evaluation of relationships between the environment and organisms, are structures consisting of calcium carbonate. The aim of this study was to realize the shape analysis. In addition, it is to detect the characteristics of otolith biometrics in order to determine the relationship between the fish size of Engraulis encrasicolus L. from the Black and Marmara Seas. The samples were obtained from the Black and Marmara Seas between December 2013 and February 2014. The relationships between the TL (Total length) and OL (Otolith length), TL and OB (Otolith breadth), and TL and $O W$ (Otolith weight) were determined using the linear regression equation. Form factor, roundness, circularity and rectangularity were used for shape analyses. According to the data, there was no difference between localities ( $\mathrm{p}>0.05)$. Moreover, there was no difference between the left and right otoliths of the individuals sampled from the same locality $(\mathrm{p}>0.05)$. According to the regression coefficient for relationships of TL-OL, TL-OB and TL-OW, otolith length was identified as the best index for estimating fish length $\left(\mathrm{r}^{2}>0.70\right)$. It showed that index values were statistically different between two populations $(\mathrm{p}<0.001)$.
\end{abstract}

Keywords: Black Sea; Engraulis encrasicolus; Marmara Sea; otolith dimensions; shape analysis

\section{ABSTRAK}

Otolit yang boleh digunakan untuk menilai hubungan antara persekitaran dan organisma, adalah struktur yang terdiri daripada kalsium karbonat. Kajian ini bertujuan untuk merealisasikan analisis bentuk. Di samping itu, ia juga bagi mengesan ciri-ciri otolit biometrik untuk menentukan hubungan antara saiz ikan Engraulis encrasicolus L. dari Laut Hitam dan Marmara. Sampel diperoleh dari Laut Hitam dan Marmara antara Disember 2013 dan Februari 2014. Hubungan antara TL (Jumlah panjang) dan OL (panjang Otolit), TL dan OB (kelebaran Otolit) serta TL dan OW (berat Otolit) telah ditentukan dengan menggunakan persamaan regresi linear. Faktor bentuk, kebundaran, kebulatan dan segi empat tepat telah digunakan untuk analisis bentuk. Mengikut data, tiada perbezaan antara lokaliti ( $\mathrm{p}>0.05)$. Selain itu, tiada perbezaan antara otolit kiri dan kanan daripada sampel dari kawasan yang sama (p $>0.05)$. Menurut pekali regresi bagi hubungan TL-OL, panjang otolit TL-OB dan TL-OW telah dikenal pasti sebagai indeks terbaik untuk menganggar panjang ikan $\left(\mathrm{r}^{2}>0.70\right)$. Ini menunjukkan bahawa nilai indeks berbeza secara statistik antara dua populasi $(\mathrm{p}<0.001)$.

Kata kunci: Analisis bentuk; dimensi otolit; Engraulis encrasicolus; Laut Hitam; Laut Marmara

\section{INTRODUCTION}

Otoliths, consist of calcium carbonate are crystallized structures located in the inner ear of fish, are an indirect means for studying fish populations and assessing the relationship between the environment and the organisms (Lord et al. 2012). These structures exhibit linear and shape morphometries, optical densities, growth characteristics and different elemental compositions (Campana 2005; DeVries et al. 2002; Leguà et al. 2013; Lord et al. 2012; Pawson \& Jennings 1996). Sagittal otoliths are primarily used in studies involving otolith morphology. The life history properties of otoliths allow accurate estimates of age and growth on both the daily and yearly scale (Campana \& Thorrold 2001). Therefore, otoliths are an important tool to record the life history of fish.
Otoliths are used in various studies such as age determination, fish growth and population dynamics. However, studies are limited to otolith morphometry. Environmental differences and geographic separation of populations resulted in certain changes in fish otoliths (Lombarte 1992; Lombarte \& Leonart 1993; Sadighzadeh et al. 2014; Torres et al. 2000; Vignon \& Morat 2010). As a result, the shape properties of otoliths are widely used in descriptions of fish stocks (Campana \& Casselman 1993; Dawson 1991).

Otolith analysis is an important marker in the studies of fish populations. The study of morphological characteristics of fish otoliths has been considered significant in recent years to stock identification (Begg \& Brown 2000; Friedland \& Reddin 1994; Reddin et al. 
1988; Tuset et al. 2003a) and systematics (Tuset et al. 2008; Williams \& McEldowney 1990).

There are several benefits in the relationship between the total length and otolith length of fish. The age and size of fish can be calculated from the otoliths obtained from the stomach of a predator (Treacy \& Crawford 1981). When the relationship between otolith length and total length in a species is determined, the total length or standard length of a fish from its otolith length can be estimated, or vice versa (Başusta et al. 2013; Battaglia et al. 2010; Sen et al. 2001; Yilmaz et al. 2014) and the otolith morphology is an additional characteristic among these species-specific criteria (Hossucu et al. 1999). In many studies, otolith shape was evaluated based on morphometric measurements (Russ 1990; Tuset et al. 2006).

Engraulis encrasicolus L. plays a major role in the fishing industry in Turkey. There are no published information on stock discrimination of E. encrasicolus using otolith analyses and dimensions. The aim of this study was to use otolith shape analysis to detect the relationships between the total length and otolith length of E. encrasicolus sampled from the Black and Marmara Seas.

\section{MATERIALS AND METHODS}

Engraulis encrasicolus specimens were obtained from commercial fishing boats at the Black and Marmara Seas ( $36^{\circ} 16^{\prime} \mathrm{E}-42^{\circ} 10^{\prime} \mathrm{N}$ and $28^{\circ} 11^{\prime} \mathrm{E}-40^{\circ} 29^{\prime} \mathrm{N}$, respectively). The coordinates were recorded using GARMIN GPS. Sampling was carried out monthly between December 2013 and February 2014.

All captured fish were measured to the nearest 0.1 $\mathrm{cm}$ for total length (TL) and weighed to the nearest 0.01 g. Sagittal otoliths were removed by making right and left distinctions. The measurements for the Black Sea (137 individuals) and Marmara Sea (126 individuals) samples were taken separately. Left and right otoliths were weighed separately using Pressicia precision scales (0.0001 g). Otolith breadth $(\mathrm{OB})$, length $(\mathrm{OL})$, area $(\mathrm{A})$ and perimeter $(\mathrm{P})$ $( \pm 0.001 \mathrm{~mm})$ were determined by Leica Application Suit Ver. 3.8 Imaging Software. All otoliths were photographed on the distal side with a Leica DFC295 digital camera. OL was defined as the greatest distance between anterior and posterior edges, and OB was defined as the greatest distance from dorsal to ventral edges (Figure 1).

The sex was determined by macroscopic examination of the gonads. Firstly, comparisons between left and right otoliths were tested by t-test. Similarly, differences between sexes were also examined by t-test. Normal distribution of all variables was determined using the KolmogorovSmirnov test. The linear regression model $(y=a+b x$, where $y$ is fish length and $x$ is otolith measurement) was applied to estimate the relationships between the otolith measurements and fish length.

Four shape index values (form factor, circularity, roundness and rectangularity) taken on the otoliths were calculated with formulas (Table 1). Form factor is a means to estimate the surface area irregularity, taking values of 1.0 when it is a perfect circle and $<1.0$ when it is irregular. Roundness and circularity give information on the similarity of various features to a perfect circle. Rectangularity describes the variations of length and width with respect to the area (Tuset et al. 2003b). SPSS 20, Minitab 15.0 and the Excel software were employed in the statistical analyses.

\section{RESULTS AND DISCUSSION}

Anchovy is one of the most important fish species to support commercial fishing in Turkey, primarily in the

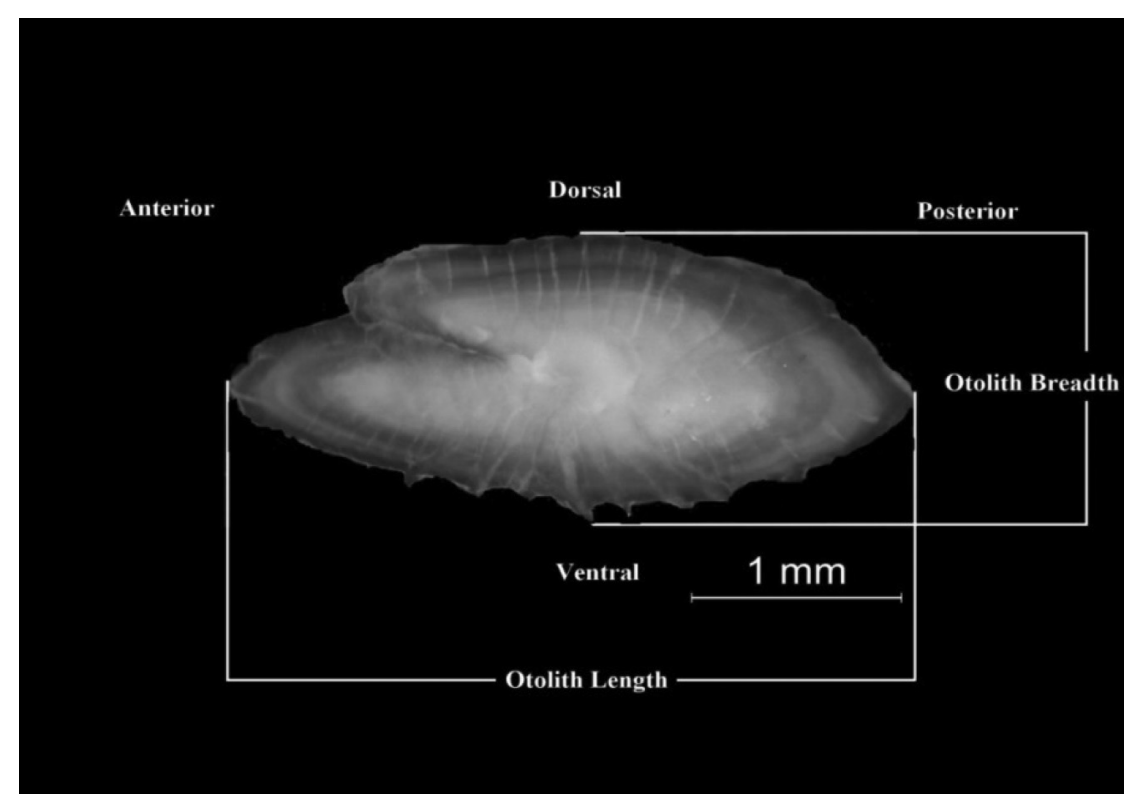

FIGURE 1. Otolith morphology of Engraulis encrasicolus 
TABLE 1. The shape indices calculated using morphometric measurements and formulas

\begin{tabular}{lcc}
\hline Parameter & Shape indices & Formula \\
\hline P (Perimeter) & Form factor & $(4 \pi \mathrm{A}) / \mathrm{P}^{2}$ \\
A (Area) & Circularity & $\mathrm{P}^{2} / \mathrm{A}$ \\
OL (Otolith Length) & Roundness & $(4 \mathrm{~A}) /\left(\pi \mathrm{OL}^{2}\right)$ \\
OB (Otolith Breath) & Rectangularity & $\mathrm{A} /(\mathrm{OL} / \mathrm{OB})$ \\
\hline
\end{tabular}

Black Sea. There are many studies on the anchovy (Caneco et al. 2004; Erdoğan et al. 2009; Gonzalez-Salas \& Lenfant 2007; Tudela 1999; Turan et al. 2004; Zorica et al. 2010). A few of these papers are on the morphometry of the anchovy species and its otolith properties. In recent years, stock discrimination has been achieved using otolith features. For this purpose, E. encrasicolus, caught from the Marmara and Black Seas, were studied and evaluated for the relationship between otolith features.

Engraulis encrasicolus $(\mathrm{N}=263)$ sampled from two different stations were used for analysis. The total length of the Marmara and Black Sea samples ranged at 9.7-14.7 and $9.3-13.0 \mathrm{~cm}$, respectively. Descriptive statistics of the Marmara and Black Sea samples are shown in Tables 2 and 3 . According to the results, there were no differences between right and left otoliths of E. encrasicolus $(p>0.05)$. Therefore, for future studies either the right or left sagittal otolith can be used. Furthermore, no differences between males and females were detected $(p>0.05)$. As a result, we used left otoliths for the subsequent analyses. In addition, the relationships between OW, OL, OB and fish size and otolith relationship between their measured values were determined separately (Figures 2-7). While otolith length and weight were significantly different from each other $(p<0.001)$ in the anchovy populations of the Black and Marmara Seas, there was no significant difference between otolith breadths. Evaluation was carried out jointly for the Marmara and Black Sea populations.

According to the regression coefficients between the relationship of fish length and otolith measurements, otolith length was found to be the best indicator for estimating the length of fish $\left(r^{2}>0.70\right)$. These results are similar to other studies in which some species belonging to Engraulidae were examined (Harvey et al. 2000; Zorica et al. 2010). Härkönen (1986) noticed that there was a strong correlation and linear relationship between fish length and otolith length. The linear regression model was preferred for the examination of the relationship between fish length and otolith characteristics in most of the studies (Basusta et al. 2013; Battaglia et al. 2010; Harvey et al. 2000; Waessle et al. 2003; Zorica et al. 2010), as such also in this study. According to this study, the otolith length was found as

TABLE 2. Descriptive statistics of Black Sea samples

\begin{tabular}{|c|c|c|c|c|c|c|c|}
\hline Loc. & Sex & Parameter & Mean & $\mathrm{SD}$ & Min. & Max. & SE \\
\hline \multirow{8}{*}{ Blacksea } & \multirow{4}{*}{ Female } & Total Length & 11.49 & 0.834 & 9.3 & 13.0 & 0.0970 \\
\hline & & Otolith Length & 2.6715 & 0.1881 & 2.1620 & 3.1230 & 0.0155 \\
\hline & & Otolith Breath & 1.3050 & 0.0905 & 1.0930 & 1.640 & 0.00744 \\
\hline & & Otolith Weight & 0.00158 & 0.00023 & 0.0009 & 0.0020 & 0.000019 \\
\hline & \multirow{4}{*}{ Male } & Total Length & 10.921 & 0.766 & 9.6 & 12.9 & 0.101 \\
\hline & & Otolith Length & 2.6227 & 0.1892 & 1.766 & 2.9190 & 0.0176 \\
\hline & & Otolith Breath & 1.2981 & 0.1042 & 1.1120 & 1.660 & 0.00967 \\
\hline & & Otolith Weight & 0.00155 & 0.00035 & 0.0006 & 0.0027 & 0.000033 \\
\hline
\end{tabular}

Loc: Locality, SD: Standard Deviation, Min: Minimum, Max: Maximum, SE: Standard Error

TABLE 3. Descriptive statistics of Marmara samples

\begin{tabular}{|c|c|c|c|c|c|c|c|}
\hline Loc. & Sex & Parameter & Mean & SD & Min. & Max. & SE \\
\hline \multirow{8}{*}{ Marmara } & \multirow{4}{*}{ Female } & Total length & 12.158 & 1.098 & 9.7 & 14.7 & 0.135 \\
\hline & & Otolith Length & 2.8152 & 0.2511 & 2.1280 & 3.4080 & 0.0219 \\
\hline & & Otolith Breath & 1.3213 & 0.0981 & 1.0320 & 1.5760 & 0.00854 \\
\hline & & Otolith Weight & 0.00176 & 0.00039 & 0.0007 & 0.00030 & 0.000035 \\
\hline & \multirow{4}{*}{ Male } & Total length & 11.853 & 0.988 & 9.8 & 14.0 & 0.133 \\
\hline & & Otolith Length & 2.7889 & 0.2196 & 2.3360 & 3.3120 & 0.0209 \\
\hline & & Otolith Breath & 1.3132 & 0.0859 & 1.1280 & 1.520 & 0.00819 \\
\hline & & Otolith Weight & 0.00171 & 0.00036 & 0.0011 & 0.0029 & 0.000035 \\
\hline
\end{tabular}

Loc: Locality, SD: Standard Deviation, Min: Minimum, Max: Maximum, SE: Standard Error 


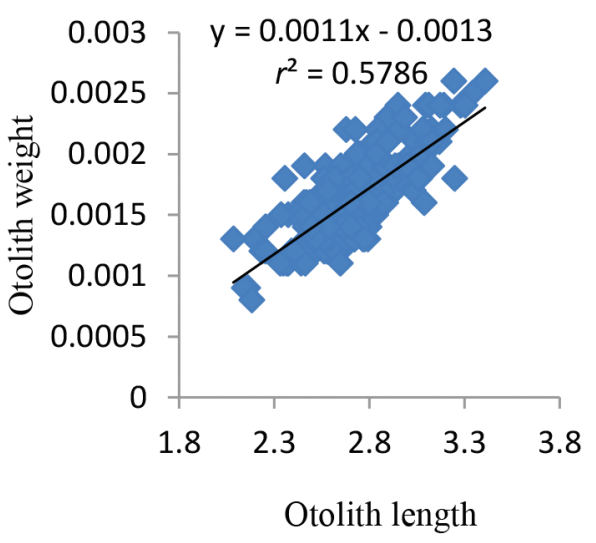

FIGURE 2. Relationship between the otolith length and otolith weight

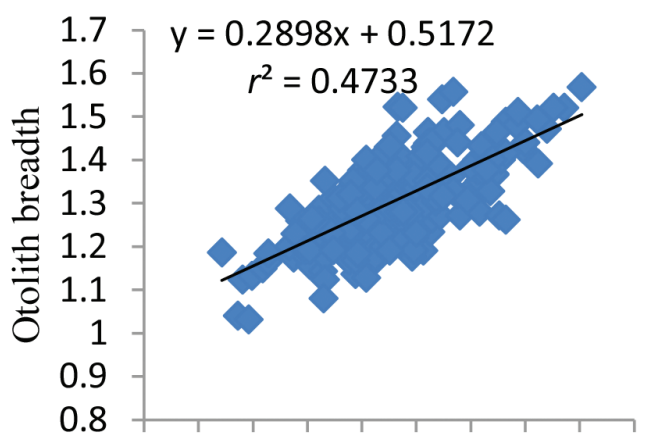

$\begin{array}{lllll}1.8 & 2 & 2.22 .42 .62 .8 & 3 & 3.23 .43 .6\end{array}$

Otolith length

FIGURE 3. Relationship between the otolith length and otolith breadth

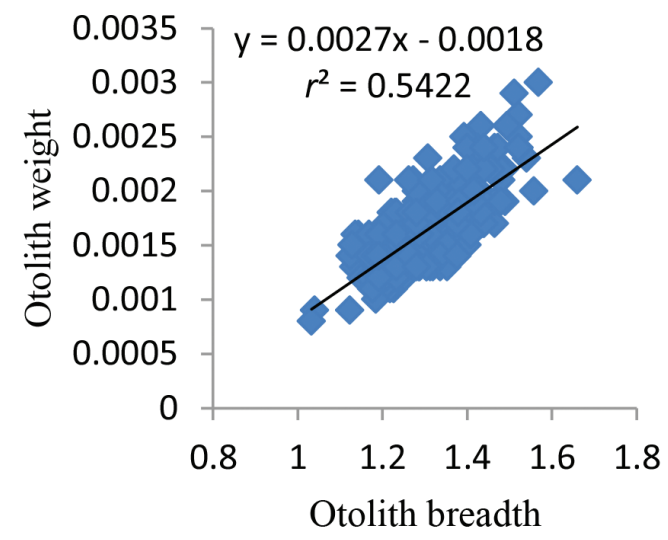

FIGURE 4. Relationship between the otolith weight and otolith breadth

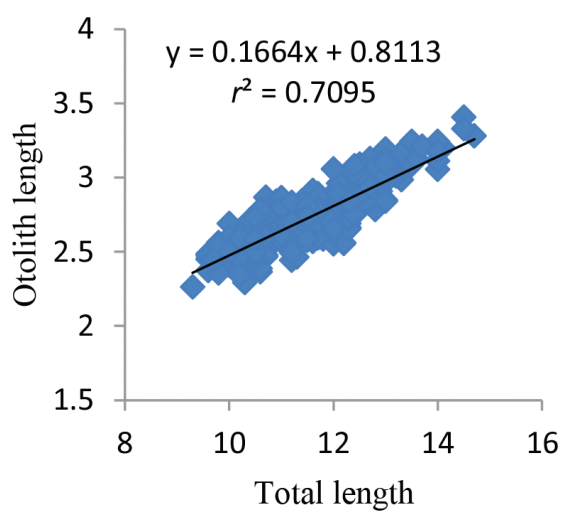

FIGURE 5. Relationship between the otolith length and total length

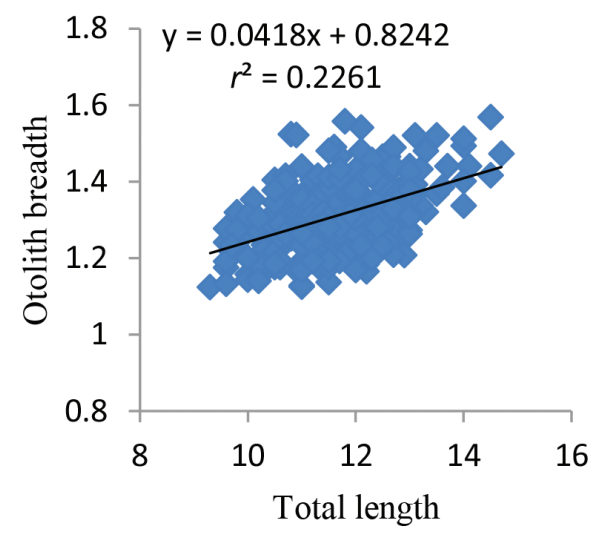

FIGURE 6. Relationship between the otolith breadth and total length

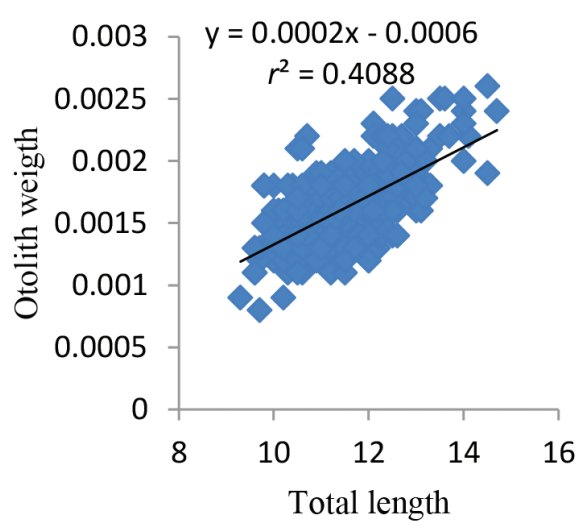

FIGURE 7. Relationship between the otolith weight and total length an ideal measurement for detecting fish length. When the regression coefficients of relationships of OL-OB, OL-OW and OB-OW were analyzed, the relationship of OW-OL was found to be the strongest $\left(r^{2}>0.57\right)$. Many studies examined the relationship between the size and otolith features of fish (Aydin et al. 2004; Basusta et al. 2013; Bostanc1 2009; Harvey et al. 2000; Hossucu et al. 1999; Waessle et al. 2003).

The minimum and maximum perimeters and areas, and shape index values of otoliths were calculated for 
TABLE 4. Shape index values, perimeter and area of otoliths according to localities

\begin{tabular}{lclc}
\hline & Black Sea & \multicolumn{2}{c}{ Marmara Sea } \\
\hline Form factor & $0.660 \pm 0.042$ & Form factor & $0.632 \pm 0.045$ \\
Roundness & $0.259 \pm 0.029$ & Roundness & $0.278 \pm 0.035$ \\
Circularity & $19.137 \pm 0.142$ & Circularity & $20.006 \pm 0,155$ \\
Rectangularity & $0.417 \pm 0.004$ & Rectangularity & $0.449 \pm 0.057$ \\
Area & $2.363 \pm 0.026$ & Area & $2.543 \pm 0.327$ \\
Perimeter & $6.701 \pm 0.041$ & Perimeter & $7.111 \pm 0.559$ \\
\hline
\end{tabular}

TABLE 5. Comparative of shape indices according to localities

\begin{tabular}{lcc}
\hline Indices & $\mathrm{P}$ & $\mathrm{F}$ \\
\hline Form factor & $0.000^{*}$ & 31.805 \\
Roundness & $0.000^{*}$ & 26.620 \\
Circularity & $0.000^{*}$ & 38.424 \\
Rectangularity & 0.422 & 0.647 \\
\hline ANOVA, $p<0.001$ & &
\end{tabular}

localities (Table 4). Samples of the Back and Marmara Seas were compared in terms of shape index values. The form factor, roundness and circularity values were found to be statistically significant, while the rectangularity did not show statistically significant difference between the localities (ANOVA, Table 5). While the otolith length increased, form factor, circularity and roundness values decreased generally. Study on shape index values for $E$. encrasicolus is quite limited (Zorica et al. 2010). Therefore, comparisons could not be made on E. encrasicolus. Many studies investigated the shape index values (Bani et al. 2013; Burke et al. 2008; Sadighzadeh et al. 2014; Torres et al. 2000; Tuset et al. 2003b; Zorica et al. 2010). The otolith shapes have been evaluated based on morphometric measurements (Short et al. 2006) and the mathematical computation of shape indices (Russ 1990; Tuset et al. 2006).

\section{CONCLUSION}

This is the first study on otolith shape and dimensions of E. encrasicolus inhabiting Black and Marmara Seas. The otolith length was found to be the most ideal measurement for determining the fish length. Three shape index values (form factor, roundness and circularity) were found to be statistically significant between the localities. The results obtained from this study can be utilized for the separation of stocks in anchovy populations using otolith dimensions. We suggest studies on genetic traits and environmental factors to be considered for otoliths of E. encrasicolus in future.

\section{REFERENCES}

Aydın, R., Calta, M., Sen, D. \& Coban, M.Z. 2004. Relationships between fish lengths and otolith length in the population of Chondrostoma regium (Heckel, 1843) inhabiting Keban Dam Lake. Pak. J. Bio. Sci. 7: 1550-1553.
Bani, A., Poursaeid, S. \& Tuset, V.M. 2013. Comparative morphology of the sagittal otolith in three species of south Caspian gobies. J. Fish Biol. 82: 1321-1332.

Basusta, A., Bal, H. \& Aslan, E. 2013. Otolith biometry - total length relationships in the population of Hazar Bleak, Alburnus heckeli (Battalgil, 1943) inhabiting Lake Hazar, Elazig, Turkey. Pak. J. Zool. 45: 1180-1182.

Battaglia, P., Malara, D., Romeo, T. \& Andaloro, F. 2010. Relationships between otolith size and fish size in some mesopelagic and bathypelagic species from Mediterranean Sea (Strait of Messina, Italy). Sci. Mar. 74: 605-612.

Begg, G.A. \& Brown, R.W. 2000. Stock identification of haddock Melanogrammus aeglefinus on Georges Bank based on otolith shape analysis. Trans. Am. Fish.Soc. 129: 935-945.

Bostanc1, D. 2009. Otolith biometry - body length relationships in four fish species (chub, pikeperch, crucian carp, and common carp). J. Freshwater Ecol. 24: 619-624.

Burke, N., Brophy, D. \& King, P.A. 2008. Shape analysis of otolith annuli in Atlantic herring (Clupea harengus): A new method for tracking fish populations. Fish.Res. 91: 133-143.

Campana, S.E. 2005. Otolith elemental composition as a natural marker of fish stocks. In Stock Identification Methods Applications in Fishery Sciences, edited by Cadrin, S.X., Friedland, K. \& Waldman, J.R. Massachusetts: Elsevier Academic Press. pp. 227-245.

Campana, S.E. \& Thorrold, S.R. 2001. Otoliths, increments, and elements: Keys to a comprehensive understanding of fish populations? Can. J. Fish Aquat. Sci. 58: 30-38.

Campana, S.E. \& Casselman, J.L. 1993. Stock discrimination using otolith shape analysis. Can. J. Fish. Aquat. Sci. 50: 1062-1083.

Caneco, B., Silva, A. \& Morais, A. 2004. Morphometric variation among anchovy (Engraulis encrasicholus L.) populations from the Bay of Biscay and Iberian waters. ICES CM 2004/EE: 24.

Dawson, W.A. 1991. Otolith measurements as a method of identifying factors affecting first year growth and stock separation of mackerel (Scomber scombrus L.). J. Cons. Int. Explor. Mer. 47: 303-317. 
DeVries, D.A., Grimes, C.B. \& Prager, M.H. 2002. Using otolith shape analysis to distinguish eastern Gulf of Mexico and Atlantic Ocean stocks of king mackerel. Fish. Res. 57: 51-62.

Erdoğan, Z., Turan, C. \& Torcu Koç, H. 2009. Morphologic and allozyme analyses of European anchovy (Engraulis encrasicolus (L. 1758)) in the Black, Marmara and Aegean Seas. Acta Adriat. 50: 77-90.

Friedland, K.D. \& Reddin, D.G. 1994. Use of otolith morphology in stock discriminations of Atlantic salmon (Salmo salar). Can. J. Fish Aquat. Sci. 51: 91-98.

Gonzales-Salas, C. \& Lenfant, P. 2007. Interannual variability and intraannual stability of the otolith shape in European anchovy Engraulis encrasicolus (L.) in the Bay of Biscay. J. Fish. Biol. 70: 35-49.

Härkönen, T.J. 1986. Guide to the Otoliths of the Bony Fishes of the Northeast Atlantic. Hellerup: Danbiu.

Harvey, J.T., Loughlin, T.R., Perez, M.A. \& Oxman, D.S. 2000. Relationship between fish size and otolith length for 63 species of fishes from the Eastern North Pacific Ocean. NOAA Technical Report NMFS 150.

Hossucu, B., Kaya, M. \& Taşkavak, E. 1999. An investigation of growth parameters and otolith-total length relationship of Solea solea (L., 1758) (Pisces: Soleidae) in İzmir Bay. Israel J. Zool. 45: 277-287.

Hunt, J.J. 1992. Morphological characteristics of otoliths for selected fish in the Northwest Atlantic. J. Northw. Atl. Fish. Sci. 13: 63-75.

Leguá, J., Plaza, G., Pèrez, D. \& Arkhipkin, A. 2013. Otolith shape analysis as a tool for stock identification of the southern blue whiting, Micromesistius australis. Lat. Am. J. Aquat. Res. 41: 479-489.

Lombarte, A. 1992. Changes in otolith area: Sensory area ratio with body size and depth. Environ. Biol. Fish. 33: 405-410.

Lombarte, A. \& Lleonart, J. 1993. Otolith size changes related with body growth, habitat depth and temperature. Environ. Biol. Fish. 37: 297-306.

Lord, C., Morat, F., Lecomte-Finiger, R. \& Keith, P. 2012. Otolith shape analysis for three Sicyopterus (Teleostei: Gobioidei: Sicydiinae) species from New Caledonia and Vanuatu. Environ. Biol. Fish. 93: 209-222.

Pawson, M.G. \& Jennings, S. 1996. A critique of methods for stock identification in marine capture fisheries. Fish. Res. 25: 203-217.

Reddin, D.G., Stansbury, D.E. \& Short, P.B. 1988. Continent of origin of Atlantic salmon (Salmo salar L.) at West Greenland. ICES J. Mar. Sci. 44: 180-188.

Russ, J.C. 1990. Computer-assisted Microscopy: The Measurement and Analysis of Images. New York: Plenum Press.

Sadighzadeh, Z., Valinassab, T., Vosugia, G., Motallebi, A.A., Fatemi, M.R., Lombarte, A. \& Tuset, V.M. 2014. Use of otolith shape for stock identification of John's snapper, Lutjanus johnii (Pisces: Lutjanidae), from the Persian Gulf and the Oman Sea. Fish. Res. 155: 59-63.

Short, J.A., Gburski, C.M. \& Kimura, D.K. 2006. Using otolith morphometrics to separate small Walleye Pollock Theragra chalcogramma from Arctic cod Boreogadus saida in mixed samples. Alaska Fish. Res. Bull. 12: 147-152.
Sen, D., Aydın, R. \& Catla, M. 2001. Relationships between fish length and otolith length in the population of Capoeta capoeta umbla (Heckel, 1843) inhabiting Hazar Lake, Elazı ğ, Turkey. Arch. Pol. Fish .9: 267-272.

Torres, G.J., Lombarte, A. \& Morales-Min, B. 2000. Sagittal otolith size and shape variability to identify geographical intraspecific differences in three species of the genus Merluccius. J. Mar. Biol. Ass. UK. 80: 333-342.

Treacy, S.D. \& Crawford, T.W. 1981. Retrieval of otoliths and statoliths from gastrointestinal contents and scats of marine mammals. J. Wildl. Manage. 45: 990-993.

Tudela, S. 1999. Morphological variability in a Mediterranean, genetically homogeneous population of the European anchovy, Engraulis encrasicolus. Fish. Res. 42: 229-243.

Turan, C., Ergüden, D., Gürlek, M., Başusta, N. \& Turan, F. 2004. Morphometric structuring of the anchovy (Engraulis encrasicolus L.) in the Black, Aegean and Northeastern Mediterranean Seas. Turk. J. Vet. Anim. Sci. 28: 865-871.

Tuset, V.M., Lombarte, A. \& Assis, C.A. 2008. Otolith atlas for the western Mediterranean, north and central eastern Atlantic. Sci. Mar. 72S1 : 7-198

Tuset, V.M., Rosin, P.L. \& Lombarte A. 2006. Sagittal otolith shape as useful tool for the identification of fishes. Fish. Res. 81: 316-325.

Tuset, V.M., Lombarte, A., Gonza'lez, J.A., Pertusa, J.F. \& Lorente, M.J. 2003a. Comparative morphology of the sagittal otolith in Serranus spp. J. Fish. Biol. 63: 1491-1504.

Tuset, V.M., Loranzo, A., Gonzàlez, J.A., Pertusa, J.F. \& GarcìaDìaz, M.M. 2003b. Shape indices to identify regional differences in otolith morphology of comber, Serranus cabrilla (L., 1758). J. Appl. Ichthyol. 19: 88-93.

Vignon, M. \& Morat, F. 2010. Environmental and genetic determinant of otolith shape revealed by a non-indigenous tropical fish. Mar. Ecol. Prog. Ser. 411: 231-241.

Waessle, J.A., Lasta, C.A. \& Favero, M. 2003. Otolith morphology and body size relationships for juvenile for juvenile Sciaenidae in the Rìo de la Plata estuary $\left(35-36^{\circ} \mathrm{S}\right)$. Sci. Mar. 67: 233-240.

Williams, R.\& McEldowney,A. 1990. A guide to the fish otoliths from waters off the Australian Antarctic Territory, Heard and Macquarie Islands. ANARE Res. Notes. 75: 1-173.

Yilmaz, S., Yazicioglu, O., Saygin (Ayaydin), S. \& Polat, N. 2014. Relationships of otolith dimensions with body length of European perch, Perca fluviatilis L., 1758 from Lake Ladik, Turkey. Pak.J.Zool.46: 1231-1238.

Zorica, B., Snovčić, G. \& Čıkeś Keč, V. 2010. Preliminary data on the study of otolith morphology of five pelagic fish species from the Adriatic Sea (Croatia). Acta Adriat. 5: 89-96.

Ondokuz Mayis University, Faculty of Art and Sciences Biology Department, Atakum

Samsun

*Corresponding author; email: melek.zengin@omu.edu.tr

Received: 4 September 2014

Accepted: 30 December 2014 